\title{
Biochemical and Docking Analysis of Substrate Interactions with Polyisoprenylated Methylated Protein Methyl Esterase
}

\author{
Randolph Duverna, Seth Y. Ablordeppey, and Nazarius S. Lamango \\ College of Pharmacy and Pharmaceutical Sciences, Florida A\&M University, Tallahassee, Florida \\ 32307
}

\section{Abstract}

Polyisoprenylated proteins (PPs) methylation by polyisoprenylated protein methyl transferase (PPMTase) is counteracted by polyisoprenylated methylated protein methyl esterase (PMPMEase). This is the only reversible step of the polyisoprenylation pathway as the relative amounts of the acid and ester forms are determined by the two competing reactions. Since PMPMEase and PPMTase may influence both the structural/functional conformations of PPs, a thorough study of these enzymes is essential to our understanding of the structural/functional features of PPs. PMPMEase has been reported under such pseudonyms as human carboxylesterase 1 (hCE1) because of its apparent broad substrate spectrum. The current study aimed to show the complementarity between its active site and the polyisoprenylated substrates that it metabolizes. Kinetics analysis was conducted with N-, S- and O-substituted substrates using porcine liver PMPMEase and docking analysis using Arguslab. Consistent with the biochemical analysis, the Sethyl analog yielded an AScore binding energy of -11.32 compared to $-13.48,-14.88,-16.15$, and $-16.81 \mathrm{kcal} / \mathrm{mol}$ for S-prenyl (C-5), S-trans-geranyl (C-10), S-trans,trans-farnesyl (C-15) and Sall trans-geranylgeranyl (C-20), respectively. The all trans-geranylgeranyl moiety provides the optimal size for active site interactions. The data reveal that the trans,trans-farnesyl and all transgeranylgeranyl groups, which are reminiscent of endogenous PPs modifications, have the highest affinity for PMPMEase. Since PPs such as monomeric G-proteins are oncogenic, PMPMEase may be viewed as a viable target for anticancer drug development. The analyses reveal the important structural elements for the design of specific PMPMEase inhibitors to serve in the modulation of oncogenic PPs activities. The results also show that hCE1's repertoire of substrates extends beyond xenobiotics to include PPs as its endogenous substrates.

\section{Introduction}

The polyisoprenylation pathway (PP) involves three sets of sequential modifications initiated by the farnesylation or geranylgeranylation of the cysteine residue of the CaaX signal motif [1]. This posttranslational modification is initiated by either a farnesyl or a geranylgeranyl transferase [2-5]. An endoprotease then cleaves the aaX tripeptide, exposing the resulting carboxylate of the polyisoprenylated cysteine to methylation by polyisoprenylated protein methyl transferase (PPMTase). The methyl esterified polyisoprenylated proteins are the substrates of a polyisoprenylated methylated protein methyl esterase (PMPMEase) that in conjunction with PPMTase render the methylation the only reversible step of the PP [6-9].

Send correspondences to: Nazarius S. Lamango, Ph.D., College of Pharmacy and Pharmaceutical Sciences, Florida A\&M University, Tallahassee, FL 32307, Tel: 850 412-7377, Fax: 850 599-3347, nazarius.lamango@ famu.edu. 
Mutations and overexpression that result in hyperactivity of polyisoprenylated monomeric G-proteins are implicated in about $30 \%$ of cancers [10] while impaired activities of some PP enzymes are linked to degenerative disorders [11,12]. The hyperactivity of the oncogenic PPs stems from mutations that destroy the autoregulatory GTPase activities of PPs such as members of the Ras family [13,14]. Overexpression of Rho family proteins also causes hyperactivity in some cancers $[15,16]$. Realizing that the PP modifications are essential for the functions of the oncogenic PPs, key enzymes of the PP have been targeted for anticancer drug development. Development of farnesylation inhibitors has been the main focus of the effort to obtain clinically useful PPs-dependent anticancer agents [17-21]. Compounds from this category have reached various phases of clinical trials $[22,23]$. The main impediment to their success has been the ability of geranylgeranyl transferase to substitute for the inhibited farnesyl transferase, ultimately compromising the antiproliferative effects of the farnesyl transferase inhibitors [24,25]. The lethality observed for PPMTase knockout mice [6] has also drawn attention to its physiological relevance and its significance as a target for anticancer drug development $[10,26]$.

Research in our lab has focused on the identification $[26,27]$ and substrate characterization of PMPMEase [28]. Porcine liver PMPMEase is 79\% identical and $88 \%$ similar to human carboxylesterase 1 (hCE1). hCE1 is a well characterized enzyme whose crystal structure in complex with various prodrug and xenobiotic molecules have been solved [29,30]. The crystallographic data shows its active site to be large, hydrophobic and flexible [30,31]. The hydrophobic nature is most likely an adaptation for interacting with the hydrophobic polyisoprenyl groups of PPs while the size and flexibility of the active site may be required to interact with the polypeptides that vary enormously in type, size and structure [30].

Previous work in our laboratory [28] used Michaelis-Menten kinetics to show a strong dependence of porcine PMPMEase on S-trans, trans-farnesylation and all transgeranylgeranylation for high affinity interactions. In the current article, the same approach was used to further characterize the nature of the active site. In addition, Arguslab version 4.0.1 (Planaria Software LLC, Seattle, WA) [31] docking software was used to determine the relative binding energies of the substrates to two hCE1 crystal structures [35,36], the rabbit homolog [37] and the model of porcine liver enzyme. The docking analyses reveal the $S$-trans, trans-farnesyl and all trans-geranylgeranyl moieties of the substrate closely interacting with hydrophobic amino acid residues in the active site and the susceptible ester bond positioned adjacent to the catalytic Ser221. The relative location of the N-4nitrobenzoyl group at the exit of the active site is noteworthy. Given that the N-4nitrobenzoyl group occupies the analogous position of the polypeptide chains in PPs, this finding is consistent with our expectations as these polypeptide portions should extend to the outside of the enzyme active site during metabolism.

\section{Materials and Methods}

\section{Materials}

Reagents were purchased either from Sigma-Aldrich (Milwaukee, WI), Acros (Morris Plains, NJ), TCI America (Portland, OR), Alfa Aesar (Ward Hill, MA) or ChemImpex International (Wood Dale, IL) and used as supplied. Flash column chromatography was run on $40-63 \mu \mathrm{SiO}_{2}$. NMR spectra were obtained on a Varian Mercury $300(300 \mathrm{MHz})$ in $\mathrm{CDCl}_{3}$, unless otherwise stated. Chemical shifts $(\delta)$ are given in ppm relative to the signal for the deuterated solvent and are reported consecutively as relative integral, multiplicity (s = singlet, $\mathrm{d}=$ doublet, $\mathrm{t}=$ triplet, $\mathrm{q}=$ quartet, $\mathrm{dd}=$ doublet of doublets, $\mathrm{m}=$ multiplet and where $\mathrm{br}=$ broad), coupling constant $(\mathrm{J} / \mathrm{Hz})$ and assignment. IR spectra were measured using Shimadzu 840S in KBr pellets. Optical rotations were measured with a JASCO $\mathrm{P}-1020$ polarimeter in a $10 \mathrm{~cm}$ cell. Elemental analysis was conducted by Atlantic Microlab, 
Inc, Norcross, GA, and are within $0.4 \%$ of the theoretical values except otherwise noted. ArgusLab 4.0.1 was obtained from Mark A. Thompson (Planaria Software LLC, Seattle, WA, www.arguslab.com).

\section{Synthesis of $\mathbf{N}$-derivatized S-farnesyl-L-cysteine methyl ester substrates}

All synthetic experiments were conducted under argon in flame-dried glassware, when required. N-substituted S-farnesyl-L-cysteine methyl esters were synthesized essentially as previously described ([32] Scheme 1). trans, trans-farnesyl-L-cysteine methyl ester (FCM) was synthesized as previously described [26-28].

\section{Synthesis of L-N-(1-naphthoic)-S-farnesyl-cysteine-O-methyl ester (L-150)}

N,N Dicyclohexyl-carbodiimide (DCC) in dichloromethane (DCM) $(0.7 \mathrm{~mL}, 0.7 \mathrm{mmol})$ was added to a stirred suspension of 1-napthoic acid (103mg, 0.60mmol) and FCM (204mg, $0.60 \mathrm{mmol})$ in anhydrous DCM $(5 \mathrm{~mL})$. The mixture was kept at $20^{\circ} \mathrm{C}$ for one day. Urea was filtered out of the solution and solvent removed under vacuum $(3 \mathrm{mmHg})$ at $35^{\circ} \mathrm{C}$ over $20 \mathrm{~min}$. The solid residue was dissolved and purified on a 40-63 $\mu$ silica gel flash column $(2.2 \times 8 \mathrm{~cm})$ eluting with a stepwise gradient of hexane- ethylacetate of 8:1 $(100 \mathrm{~mL})$ and 5:1 $(100 \mathrm{~mL})$. The solvent was removed under vacuum to obtain the yellowish oil $(251 \mathrm{mg}$, 54\%). ${ }^{1} \mathrm{H}-\mathrm{NMR}: \delta 1.42\left(\mathrm{~s}, \mathrm{CH}_{3}\right), 1.42\left(\mathrm{~s}, \mathrm{CH}_{3}\right), 1.66\left(\mathrm{~s}, \mathrm{CH}_{3}\right), 1.95-2.09\left(\mathrm{~m}, 4 \times \mathrm{CH}_{2}\right)$, 3.02-3.11( $\beta^{\prime}$ and $\beta$ ) (dd, S-C-H J=7.5Hz), 3.012-3.24 (t, $\left.\mathrm{CH}_{2} \mathrm{~S}, J=7.2 \mathrm{~Hz}\right), 3.81\left(\mathrm{~s}, \mathrm{OCH}_{3}\right)$,

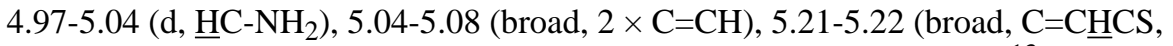
$J=1.2 \mathrm{~Hz}$ ), 7.52-7.56 (d, Ar), 7.84-7.93 (d, Ar), 8.35 (d, HN, $J=10.2 \mathrm{~Hz}) .{ }^{13} \mathrm{C}-\mathrm{NMR}: \delta 16.27$, $16.38,17.82,25.89,26.64,26.95,30.38,33.76,39.83,39.91,52.60,52.91,119.8,123.8$, 124.0, 124.6, 127.01, 128.0, 128.7, 129.25, 131.2, 131.5, 132.8, 135.2, 140.4, 167.3, 171.8 . Calcd for $\mathrm{C}_{30} \mathrm{H}_{39} \mathrm{NO}_{3} \mathrm{~S}: \mathrm{C}, 72.98 ; \mathrm{H}, 7.96 ; \mathrm{N}, 2.84$. Found: C, 72.89; H, 8.01; N, 2.82.

\section{Synthesis of L-N-(2-Naphthoic)-S-trans, trans-farnesyl-cysteine methyl ester (L-151)}

Triethylamine (TEA, $181 \mu \mathrm{L}, 1.32 \mathrm{mmol}$ ) was added to a stirred suspension of 2-Naphthoyl chloride $(114 \mathrm{mg}, 0.6 \mathrm{mmol})$ and FCM $(204 \mathrm{mg}, 0.6 \mathrm{mmol})$ in anhydrous DCM $(10 \mathrm{~mL})$ on ice. After $10 \mathrm{~min}$, the mixture was left at RT for $4 \mathrm{~h}$. The solvent was removed under vacuum and the solid residue dissolved in ethylacetate. The organic phase was washed with cold 5\% $\mathrm{NaHCO}_{3}, 10 \% \mathrm{HCl}$ and brine, dried over $\mathrm{MgSO}_{4}$ and the solvent removed under vacuum. The resulting oil was purified by flash chromatography on a silica gel column eluting with DCM to afford a solid (108mg, 36.5\%). ${ }^{1} \mathrm{H}-\mathrm{NMR}$ : $\delta 1.42\left(\mathrm{~s}, \mathrm{CH}_{3}\right), 1.58$ (s, $\left.\mathrm{CH}_{3}\right), 1.66\left(\mathrm{~s}, \mathrm{CH}_{3}\right), 1.96-2.10\left(\mathrm{~m}, 4 \times \mathrm{CH}_{2}\right), 3.02-3.11\left(\beta^{\prime}\right.$ and $\left.\beta\right)(\mathrm{dd}, \mathrm{S}-\mathrm{C}-\mathrm{H} J=7.5 \mathrm{~Hz})$, 3.012-3.24 (t, $\left.\mathrm{CH}_{2} \mathrm{~S}, J=7.2 \mathrm{~Hz}\right), 3.81\left(\mathrm{~s}, \mathrm{OCH}_{3}\right), 4.97-5.04\left(\mathrm{~d}, \underline{\mathrm{HC}}-\mathrm{NH}_{2}\right), 5.04-5.08$ (br, $2 \times$ $\mathrm{C}=\mathrm{CH})$, 5.21-5.22 (br, C=CHCS), 7.32-7.46 (d, Ar), 7.62-7.70 (d, Ar), 7.79-7.82 (d, Ar), 7.84-7.93 (d, Ar), 8.35 (d, HN, $J=10.2 \mathrm{~Hz}$ ). ${ }^{13} \mathrm{C}-\mathrm{NMR}$ : $\delta 16.27,16.38,17.82,19.6,25.89$, 26.64, 26.95, 30.38, 33.76, 39.83, 39.91, 52.60, 52.91, 119.8, 123.8, 124.0, 124.6, 127.01, 128.0, 128.7, 129.25, 131.2, 131.5, 132.8, 135.2, 140.4, 167.3, 171.8. Calcd for $\mathrm{C}_{30} \mathrm{H}_{39} \mathrm{NO}_{3} \mathrm{~S}: \mathrm{C}, 72.98 ; \mathrm{H}, 7.96 ; \mathrm{N}, 2.84$. Found: C, 72.89; H, 8.02; N, 2.79.

\section{L-N-(4-Phenylbenzoyl)-S-trans, trans-farnesyl-cysteine methyl ester (L-152)}

A $1 \mathrm{~N}$ solution of DCC in DCM $(1.5 \mathrm{~mL}, 1.5 \mathrm{mmol})$ was added to a stirred suspension of 4phenylbenzoic acid (119 mg, $0.6 \mathrm{mmol})$ and FCM $(204 \mathrm{mg}, 0.6 \mathrm{mmol})$ in anhydrous DCM $(10 \mathrm{~mL})$ and the mixture was kept at RT for one day. Dicyclohexylurea (DCU) was filtered out and the solvent removed under vacuum. The residue was dissolved in DCM and separated on a flash column on a stepwise gradient of Hexane- ethylacetate 10:1 to 2:1. Crystallization from methanol with activated carbon gave yellow solid (30mg, $9.6 \%$ ); mp 77-79 ${ }^{\circ} \mathrm{C} ;[\alpha]_{\mathrm{D}}{ }^{20}=-27.78 .{ }^{1} \mathrm{H}-\mathrm{NMR}: \delta 1.55-1.60\left(\mathrm{~s}, \mathrm{CH}_{3}\right), 1.61-1.66\left(\mathrm{~s}, \mathrm{CH}_{3}\right), 1.59\left(\mathrm{~s}, \mathrm{CH}_{3}\right)$, $1.66\left(\mathrm{~s}, \mathrm{CH}_{3}\right), 1.93-2.10\left(\mathrm{~m}, 4 \times \mathrm{CH}_{2}\right), 2.82-2.90\left(\mathrm{H}_{\beta}\right)$ and $2.95-3.01\left(\mathrm{H}_{\beta^{\prime}}\right)(\mathrm{dd}, \mathrm{S}-\mathrm{C}-\mathrm{H}$ 
$J=7.5 \mathrm{~Hz}), 3.01-3.24\left(\mathrm{t}, \mathrm{CH}_{2} \mathrm{~S}, J=7.2 \mathrm{~Hz}\right), 3.77\left(\mathrm{~s}, \mathrm{OCH}_{3}\right), 4.276(\mathrm{~d}, 2 \times), 4.78-4.84(\mathrm{t}, \underline{\mathrm{HC}}-$ $\left.\mathrm{NH}_{2}\right), 5.05-5.09(\mathrm{~m}, 2 \times \mathrm{C}=\mathrm{CH}), 5.15-5.20(\mathrm{~m}, \mathrm{C}=\mathrm{C} \underline{\mathrm{HCS}}, J=1.2 \mathrm{~Hz}), 7.21-7.27(\mathrm{~d}, \mathrm{HN}$, $J=10.2 \mathrm{~Hz}$ ), 7.58 (s, NH), 7.98 (m, Ar, 2H, 2H), 8.27 (m, Ar, 2H, 2H). ${ }^{13} \mathrm{C}-\mathrm{NMR}: \delta 16.27$, 16.39, 17.95, 25.97, 26.64, 26.93, 30.07, 33.28, 39.87, 39.27, 43.71, 52.25, 53.08, 119.6, 123.8, 124.0, 124.5, 128.7, 131.6, 135.7, 139.2, 140.5, 149.9, 165.8, 168.9, 171.3. Calcd for $\mathrm{C}_{32} \mathrm{H}_{41} \mathrm{NO}_{3} \mathrm{~S}: \mathrm{C}, 73.95 ; \mathrm{H}, 7.95 ; \mathrm{N}, 2.69$. Found: C, 73.67; H, 8.00; N, 2.69.

\section{L- N-(3, 5 Dinitrobenzoic)-S-farnesyl-cysteine-O-methyl ester (L-155)}

DCC in DCM $(0.7 \mathrm{~mL}, 0.7 \mathrm{mmole})$ was added to a stirred suspension of 3,5 dinitrobenzoic acid $(191 \mathrm{mg}, 0.90 \mathrm{mmol})$ and FCM $(306 \mathrm{mg}, 0.90 \mathrm{mmol})$ in anhydrous DCM $(5 \mathrm{~mL})$. The mixture was kept at $20^{\circ} \mathrm{C}$ for one day. Urea was filtered out of the solution and the solvent removed under vacuum $(3 \mathrm{mmHg})$ at $35^{\circ} \mathrm{C}$. The solid residue was dissolved in a hexaneethylacetate (8:1) mixture and applied on a $40-63 \mu$ silica gel flash-column $2.2 \times 8 \mathrm{~cm}$, eluting with a stepwise gradient of hexane- ethylacetate from 8:1 $(100 \mathrm{~mL})$ to $5: 1(100 \mathrm{~mL})$. The solvent was removed and the product dried under vacuum yielding yellow oil $(251 \mathrm{mg}$, 54\%). $[\alpha]^{24}{ }_{\mathrm{D}}=-63.7 .{ }^{1} \mathrm{H}-\mathrm{NMR}: \delta 1.57\left(\mathrm{~s}, \mathrm{CH}_{3}\right), 1.63\left(\mathrm{~s}, \mathrm{CH}_{3}\right), 1.66\left(\mathrm{~s}, \mathrm{CH}_{3}\right), 1.94-2.10(\mathrm{~m}, 4$ $\left.\times \mathrm{CH}_{2}\right), 3.08-3.10\left(\beta^{\prime}\right.$ and $\left.\beta\right)(\mathrm{d}, \mathrm{S}-\mathrm{C}-\mathrm{H} J=7.5 \mathrm{~Hz}), 3.19-3.21\left(\mathrm{~d}, \mathrm{CH}_{2} \mathrm{~S}, J=7.2 \mathrm{~Hz}\right), 3.81(\mathrm{~s}$, $\left.\mathrm{OCH}_{3}\right)$, 4.52-4.55 (d, $\left.\underline{\mathrm{HC}}-\mathrm{NH}_{2}\right)$, 5.03-5.07 (br, $\left.2 \times \mathrm{C}=\mathrm{CH}\right), 5.20-5.21$ (br, $\mathrm{C}=\mathrm{C} \underline{\mathrm{HCS}}$, $J=1.2 \mathrm{~Hz}), 7.86-7.890(\mathrm{~d}, \mathrm{HN}, J=10.2 \mathrm{~Hz}), 8.26(\mathrm{~d}, \mathrm{Ar}), 9.10-9.12\left(\mathrm{~d}, \mathrm{Ar} \mathrm{O}_{2} \mathrm{~N}-\mathrm{CH}-\mathrm{NO}_{2}\right) .{ }^{13} \mathrm{C}-$ NMR: $\delta$ 16.2, 16.4, 17.9, 25.9, 26.6, 26.9, 30.5, 33.5, 39.8, 39.9, 53.4, 56.2, 114.4, 119.5, $123.8,124.4,124.5,130.5,131.5,131.5,135.7,137.1,140.8,147.3,163.0,170.2$. Calcd for $\mathrm{C}_{26} \mathrm{H}_{35} \mathrm{~N}_{3} \mathrm{O}_{7} \mathrm{~S}: \mathrm{C}, 58.52 ; \mathrm{H}, 6.61 ; \mathrm{N}, 7.87$; Found: $\mathrm{C}, 59.01 ; \mathrm{H}, 6.62 ; \mathrm{N}, 7.87$.

\section{L-N-(3-nitrobenzoyl)-S-trans, trans-farnesyl-cysteine methyl ester (L-156)}

TEA (181 $\mu \mathrm{L}, 1.32 \mathrm{mmol})$ was added to a stirred suspension of FCM (393 mg, $1.15 \mathrm{mmol})$ in anhydrous DCM $(10 \mathrm{~mL})$ on ice. 3-Nitrobenzoyl chloride $(273 \mathrm{mg}, 1.47 \mathrm{mmol})$ in DCM was added drop-wise to the reaction mixture. After $60 \mathrm{~min}$ on ice, the mixture was left at RT for $4 \mathrm{~h}$. The solvent was removed under vacuum and the solid residue dissolved in ethyl acetate, washed with cold $5 \% \mathrm{NaHCO}_{3}, 10 \% \mathrm{HCl}$ and brine and dried over $\mathrm{MgSO}_{4}$. The solvent was evaporated and the resulting oil purified by flash chromatography on a silica gel column eluting with hexane- ethylacetate (3:1) to give a solid (440.4mg, 77\%). ${ }^{1} \mathrm{H}-\mathrm{NMR}$ : $\delta 1.58\left(\mathrm{~s}, \mathrm{CH}_{3}\right), 1.59\left(\mathrm{~s}, \mathrm{CH}_{3}\right), 1.66\left(\mathrm{~s}, \mathrm{CH}_{3}\right), 1.94-2.10\left(\mathrm{~m}, 4 \times \mathrm{CH}_{2}\right), 2.98-3.09\left(\beta^{\prime}\right.$ and $\beta$ ) (dd, S-C-H J=8.1Hz), 3.11-3.66 (t, $\left.\mathrm{CH}_{2} \mathrm{~S}, J=7.2 \mathrm{~Hz}\right), 3.82\left(\mathrm{~s}, \mathrm{OCH}_{3}\right), 4.97-5.03$ (d, $\underline{\mathrm{HC}}-$ $\mathrm{NH}_{2}$ ), 5.05-5.08 (br, $\left.2 \times \mathrm{C}=\mathrm{CH}\right), 5.10-5.24(\mathrm{br}, \mathrm{C}=\mathrm{C} H \mathrm{HC}, J=1.5 \mathrm{~Hz}), 7.01-7.26(\mathrm{~d}, \mathrm{HN}$, $J=7.5 \mathrm{~Hz}$ ), 7.64-7.69 (t, Ar), 8.15-8.19 (d, Ar), 8.37-8.41, (d, Ar). 8.66-8.67 (d, Ar). ${ }^{13} \mathrm{C}-$ NMR: $\delta 16.38,16.38,17.82,25.9,26.9,30.3,33.6,39.8,39.9,52.6,53.1,119.6,122.5$, 123.86, 124.2, 126.6, 130.1, 131.1, 133.2, 135.5, 140.1, 145.1, 167.6, 171.1. Calcd for $\mathrm{C}_{26} \mathrm{H}_{36} \mathrm{~N}_{2} \mathrm{O}_{5} \mathrm{~S}: \mathrm{C}, 63.91 ; \mathrm{H}, 7.43 ; \mathrm{N}$, 5.73. Found: $\mathrm{C}, 63.72 ; \mathrm{H}, 7.26 ; \mathrm{N}, 5.64$.

\section{L-N-(2-nitrobenzoyl)-S-trans, trans-farnesyl-cysteine methyl ester (L-157)}

TEA (181 $\mu \mathrm{L}, 1.32 \mathrm{mmol})$ was added to a stirred suspension of FCM (427.8 mg, $1.47 \mathrm{mmol})$ in anhydrous DCM (10 mL) on ice. 2-Nitrobenzoyl chloride (273 mg, $1.47 \mathrm{mmol})$ in DCM was added drop-wise to the reaction mixture. After $60 \mathrm{~min}$ on ice, the reaction mixture was left at RT for $4 \mathrm{~h}$. The solvent was removed under vacuum and the solid residue dissolved in ethyl acetate and washed with cold $5 \% \mathrm{NaHCO}_{3}, 10 \% \mathrm{HCl}$ and brine and dried over $\mathrm{MgSO}_{4}$. The solvent was evaporated and the resulting oil purified by flash chromatography on a silica gel column, eluting with DCM to give a solid (313mg, 43.4\%). ${ }^{1} \mathrm{H}-\mathrm{NMR}$ : $\delta 1.60$ (s, $\left.\mathrm{CH}_{3}\right), 1.68\left(\mathrm{~s}, \mathrm{CH}_{3}\right), 1.72\left(\mathrm{~s}, \mathrm{CH}_{3}\right), 1.95-2.10\left(\mathrm{~m}, 4 \times \mathrm{CH}_{2}\right), 2.99-3.06$ ( $\beta^{\prime}$ and $\left.\beta\right)$ (dd, $\mathrm{S}-$ C-H $J=5.7 \mathrm{~Hz}), 3.10-3.29$ (t, $\left.\mathrm{CH}_{2} \mathrm{~S}, J=13.8 \mathrm{~Hz}\right), 3.82\left(\mathrm{~s}, \mathrm{OCH}_{3}\right), 4.99-5.06(\mathrm{~d}, \underline{\mathrm{HC}}-\mathrm{NH})$, 5.07-5.11 (br, $2 \times \mathrm{C}=\mathrm{CH}), 5.20-5.25$ (br, C=CHCS, $J=5.4 \mathrm{~Hz}), 6.64-6.66(\mathrm{~d}, \mathrm{HN}, J=7.8 \mathrm{~Hz})$, 7.26-7.62 (t, Ar), 7.66-7.69 (t, Ar), 8.06-8.09, (d, Ar). ${ }^{13} \mathrm{C}-\mathrm{NMR}: \delta 16.38,16.38,17.82$, 25.9, 26.9, 30.3, 33.6, 39.8, 39.9, 52.6, 53.1, 119.6, 122.5, 123.86, 124.2, 126.6, 130.1, 
131.1, 133.2, 135.5, 140.1, 145.1, 167.6, 171.1. Calcd for $\mathrm{C}_{26} \mathrm{H}_{36} \mathrm{~N}_{2} \mathrm{O}_{5} \mathrm{~S}: \mathrm{C}, 63.91 ; \mathrm{H}, 7.43$; N, 5.73. Found: C, 64.16; H, 7.52; N, 5.78.

\section{L- N-(2-(methoxycarbonyl) benzyl)-S-farnesyl-cysteine-O-methyl ester (L-158)}

DCC in DCM $(0.7 \mathrm{~mL}, 0.7 \mathrm{mmol})$ was added to a stirred suspension of 2-(methoxycarbonyl) benzoic acid $(109 \mathrm{mg}, 0.60 \mathrm{mmol})$ and FCM $(204 \mathrm{mg}, 0.60 \mathrm{mmol})$ in anhydrous DCM $(5 \mathrm{~mL})$. The mixture was kept at $20^{\circ} \mathrm{C}$ for one day. Urea was filtered out of the solution and the solvent removed under reduced pressure $\left(3 \mathrm{mmHg}\right.$ ) at $35^{\circ} \mathrm{C}$ for $20 \mathrm{~min}$. The solid residue was dissolved in hexane- ethylacetate (10:1) mixture and purified on 40-63 $\mu$ flash silica gel column $(2.2 \times 8 \mathrm{~cm})$ eluting with a stepwise gradient of hexane- ethylacetate $10: 1(90 \mathrm{~mL})$ to 2:1 $(100 \mathrm{~mL})$. The solvent was removed under vacuum to obtain a white solid $(150 \mathrm{mg}$, 49.8\%). $[\alpha]^{24}{ }_{\mathrm{D}}=-36.92 .{ }^{1} \mathrm{H}-\mathrm{NMR}: \delta 1.58\left(\mathrm{~s}, \mathrm{CH}_{3}\right), 1.67\left(\mathrm{~s}, \mathrm{CH}_{3}\right), 1.67\left(\mathrm{~s}, \mathrm{CH}_{3}\right), 1.97-2.10$ $\left(\mathrm{m}, 4 \times \mathrm{CH}_{2}\right), 2.96-3.00\left(\beta^{\prime}\right.$ and $\beta$ ) (d, S-C-H J=7.5Hz), 3.10-3.23 (d, $\left.\mathrm{CH}_{2} \mathrm{~S}, J=7.2 \mathrm{~Hz}\right), 3.79$ $\left(\mathrm{s}, \mathrm{OCH}_{3}\right), 3.86\left(\mathrm{~s}, \mathrm{OCH}_{3}\right), 4.99-5.05\left(\mathrm{~d}, \underline{\mathrm{HC}}-\mathrm{NH}_{2}\right)$, 5.06-5.09 (br, $\left.2 \times \mathrm{C}=\mathrm{CH}\right), 5.10-5.23$ (br, C=CHCS, $J=1.2 \mathrm{~Hz}$ ), 7.46-7.51 (d, HN, $J=10.2 \mathrm{~Hz}), 7.52-7.54$ (d, Ar), 7.85-7.88 (d, Ar). ${ }^{13}$ C-NMR: $\delta 16.2,16.3,17.9,25.9,26.6,26.9,30.3,33.7,39.8,39.9,52.5,52.67$, 52.76, 119.9, 123.9, 124.5, 127.9, 129.6, 130.0, 130.3, 131.4, 132.1, 135.5, 137.7, 140.2, 167.1, 169.0, 171.4. Calcd for $\mathrm{C}_{28} \mathrm{H}_{39} \mathrm{NO}_{5} \mathrm{~S}: \mathrm{C}, 67.03 ; \mathrm{H}, 7.84 ; \mathrm{N}, 2.79$. Found: C,66.80; H, $7.72 ; \mathrm{N}, 2.83$.

\section{Enzyme Kinetics Analysis}

The putative substrates were screened for hydrolysis by PMPMEase as previously described [27-29]. Hydrolyzed compounds (substrates) were subjected to Michaelis-Menten kinetics analysis as described previously [28]. Varying concentrations of each substrate (3-1000 $\mu \mathrm{M})$ were incubated with PMPMEase ( 0.1 to $5 \mu \mathrm{g}$ ) in $100 \mathrm{mM}$ Tris- $\mathrm{HCl}$, pH 7.4 containing 5\% DMSO at $37^{\circ} \mathrm{C}$ in a total incubation volume of $100 \mu \mathrm{L}$. Reactions were stopped by adding $200 \mu \mathrm{L}$ of methanol. They were then placed on ice for at least $5 \mathrm{~min}$ before centrifugation at $5000 \times g$ for $5 \mathrm{~min}$. The supernatants were removed and analyzed by RP-HPLC with UV detection at $260 \mathrm{~nm}$ as previously described [27-29]. The product peak areas were measured and used to quantify the amount of product formed using a calibration plot of known amounts of product against peak area. All experiments were conducted in triplicates.

\section{Porcine Liver Esterase Modeling}

The crystal structure of porcine liver PMPMEase used in the biochemical analysis has not been solved. On the other hand, hCE1 shares $79 \%$ sequence identity and $88 \%$ sequence similarity to porcine liver PMPMEase [27]. It is thus believed to be the human version of porcine liver enzyme. Therefore, in the absence of a crystal structure for the porcine enzyme, those for hCE1 with various bound hydrophobic ligands [29,30,33] were considered for docking studies. The structures reveal an active site that is large, flexible and hydrophobic $[31,34]$. These have been suggested to be the essential elements for binding the polyisoprenes as well as for accommodating the large, structurally varied polypeptides [27]. Furthermore, one of the crystal structures of hCE1 (PDB: 1YAH [33]) was used as a template to construct a structural model for the porcine liver enzyme. To achieve this, the amino acid sequence of porcine liver esterase (Accession: Q29550) was retrieved from the SWISS PROT database and aligned with the sequence of hCE1 used for PDB: 1YAH. The porcine PMPMEase model structure (PLE) was then constructed using the MODELLER program [34]. 


\section{Docking of N, S, O-substituted cysteine methyl ester analogs to the active site of various} PMPMEase

Crystallized human carboxylesterase (1YAH) has an ethyl acetate, an analog of fatty acid ethyl ester, bound to the active site [34]. The ethyl acetate was used to create a ligandbinding site for the substrates. This includes various amino acids that lie within a defined pocket. The active site residues were used to create the binding sites for the other human (1MX5) [35,36], porcine (PLE) and rabbit (1K4Y)[37] PMPMEase isoforms. ArgusLab Version 4.01 software was used for the docking analyses. Procedures for the docking of substrates were essentially as previously described [38]. Briefly, a Chemdraw structure for each compound was first saved as an MDL Molfile and opened in ArgusLab. The atoms were then set to the appropriate hybridizations ( $\mathrm{sp} 3, \mathrm{sp} 2$, etc) followed by the addition of the hydrogen atoms. The geometry of each compound was optimized before it was made into a ligand using the "Make a Ligand Group from this Residue" option of the ArgusLab software. The docking between the binding site and each substrate was performed using the "Dock a ligand" option. A maximum number of 500 poses was set in order to increase the binding precision. All the amino acid residues of the ethyl acetate binding site were defined to be part of the binding site using a cubic box measuring $18 \times 18 \times 22$ points built to include the entire active site. All other docking analysis parameters were set as previously described [38]. Spacing between the grid points was set at $0.4 \AA$ A. "ArgusDock" and "Dock" were chosen as the docking engine for the simulations and calculation type, respectively. "Flexible" was chosen for the ligand and "Ascore" for the scoring function. The binding energies for the ligands (substrates) were calculated with parameters from the AScore.prm file using the AScore function. Ligands that were previously defined, from ligand setup, were then docked and the AScore energies recorded. Poses were rank-ordered by docking energy and the pose with the lowest energy was chosen as the predicted receptor-bound conformation of the ligand. These poses were examined to confirm the position of the susceptible ester bond relative to the catalytic Ser 221 residue. Molecular viewing was conducted with Visual Molecular Dynamics (VMD) software [39].

\section{Results}

\section{Synthesis of N-substituted S-Farnesylated Cysteine Methyl Ester Analogs}

Substrates were synthesized according to scheme 1. Once purified, each compound was analyzed by thin layer chromatography, proton and carbon-13 NMR and elemental analysis. The melting points for solid compounds and optical rotations for chiral compounds were determined. The yields ranged from 30 to $60 \%$ and the purity of the compounds was close to 99\% as determined by NMR, elemental analysis and HPLC.

\section{Michaelis-Menten kinetics analysis of $\mathrm{N}$-substituted S-farnesylated cysteine methyl ester analogs}

When the synthesized compounds were initially screened for hydrolysis by PMPMEase, all the compounds except L-152 with the 4-phenyl benzoic acid group were hydrolyzed. The Michaelis-Menten kinetics data show significant differences with respect to the nature of the $\mathrm{N}$-substitutions (Fig. 1, Table 1). L-157 with an N-2-nitrobenzoyl substituent had an approximately 2-fold lower $K_{\mathrm{M}}(14 \mu \mathrm{M})$ than the N-3-nitrobenzoyl (L-156, $\left.36 \mu \mathrm{M}\right)$ and the $\mathrm{N}$-4-nitrobenzoyl (RD-PNB, $29 \mu \mathrm{M}$ ) substituents. The preference for ortho-substitution is further exemplified by L-158. N-substituents that involved para-substitutions were generally not preferred as the $K_{\mathrm{M}}$ for L-151 $(91 \mu \mathrm{M})$ is over 3-fold larger than that for L-150 $(25 \mu \mathrm{M})$. The affinity of substrates towards the enzyme was inversely related to the turnover rate as decreasing $K_{\mathrm{M}}$ values were associated with decreases in the Vmax or $\mathrm{k}_{\text {cat }}$ values for each substrate (Table 1). Although L-152 was not hydrolyzed, it inhibited the hydrolysis of RDPNB substrate with a Ki of $190 \mu \mathrm{M}$. 


\section{Docking analysis reveals highly complementary enzyme-polyisoprenylated cysteinyl ester substrate interactions}

While no crystal structure exists for porcine liver PMPMEase, human carboxylesterase 1 has been co-crystallized with ethyl acetate in the active site [33]. Although the $K_{\mathrm{M}}$ data obtained with the porcine isoform had been the main parameter for gauging the relative affinity of the substrates, docking analysis with Arguslab facilitated the determination of the relative binding energies for the N-, S- and O-substituted analogs to the human enzyme. As shown in Table 2, the relative binding energies follow the same general profiles as the MichaelisMenten constants for the variations of the S-substitutions. When the $\mathrm{N}$ - and O-substituents were the same and the S-substituents varied, significant and systematic differences in AScore docking energies and interactions with active site residues were observed. As shown in Table 2, increasing the size of the S-alkyl substituent from ethyl to all transgeranylgeranyl resulted in decreased AScore docking energies that correspond with increasing binding affinities. Consistent with the biochemical analysis that employed the porcine enzyme, the docking energies (AScore values) were in the order ethyl (L-74) < prenyl $(\mathrm{L}-77)<$ trans-geranyl $(\mathrm{L}-72)<$ trans, trans-farnesyl $(\mathrm{RD}-\mathrm{PNB})<$ all transgeranylgeranyl (L-80) (Table. 2). As expected, the all trans-geranylgeranyl group is embedded within the hydrophobic amino acids in the active site (Fig. 2). This progressive increase in binding affinities can be attributed to the increased interactions between the increasingly larger S-alkyl groups and active site hydrophobic amino acid side chains (Fig. 3 and Table 3). The hydrophobic active site residues include Ser221, His468, Glu354, Gly142 and 143, Ile 359, Leu 97, 255, 304, and 363, Phe426, and Val146 and254. While L-80 with the largest S-alkyl group is able to "snake" around the active site to interact with these residues, RD-PNB whose S-alkyl group is 5-carbon atoms less is comparatively limited in the number of interactions (Fig. 2, Fig. 3 and Table 3). The other substrates with increasingly shorter S-substituents display progressively lower binding affinities with the decreasing S-alkyl sizes showing correspondingly fewer active site interactions (Fig. 2).

S-alkyl bond saturation and modifications affect the affinity of substrates. A 3-fold difference in $K_{\mathrm{M}}$ was observed between L-77 with an S-prenyl (5-carbon unsaturated substituent) and L-81which has an S-2-methyl butane substituent. This difference in affinity is shown in the AScore docking energies for L-77 and L-81 of -13.48 and $-12.61 \mathrm{kcal} / \mathrm{mole}$, respectively. Small differences in the AScore docking energies between L-72 and the two partially saturated enantiomers (L-83 and L-86) mirror the observations in their respective $K_{\mathrm{M}}$ values. The AScore binding energies for the O-alkyl substitutions also reflect the $K_{\mathrm{M}}$ values for these substrates as the AScore binding energies decreased with increasing O-alkyl size from RD-PNB (-16.15 kcal/mole) through L-76 (-16.48 kcal/mole) to L-75 (-18.65 kcal/ mole). The effect of $\mathrm{N}$-substitution is more ambiguous as L-152 was not metabolized and the AScore binding energies correlate less with the $K_{\mathrm{M}}$ values. Of the N-nitrobenzoyl substituents, the 2-nitro (L-157, -17.59 kcal/mole) is preferred over 3-nitro (L-156, -15.90 $\mathrm{kcal} / \mathrm{mole}$ ) and 4-nitro (RD-PNB, -16.15 Kcal/mole) groups. L-155 with the 3,5dinitrobenzoyl substituent displayed a relatively low value that was not reflected in the corresponding AScore binding energy. It thus appears that the Michaelis-Menten constants obtained with porcine liver PMPMEase correlate well with the docking energies only for the $\mathrm{S}$ - and O-substituted substrates. When the AScore binding energies for 1YAH, PLE, 1K4Y and 1MX5 structures were plotted against the $\mathrm{p} K_{\mathrm{M}}$ for the S-alkylated substrates, $\mathrm{r}^{2}$ values of $0.7499,0.7003,0.7407$ and 0.8266 were observed for the respective structures. These are higher than those for the N-substituted compounds in which $\mathrm{r}^{2}$ values of $0.05273,0.02796$, 0.4108 and 0.1571 were observed (Fig. 4). The 1K4Y crystal structure is that obtained with a bound product from the hydrolysis of the anticancer drug CPT-11 [37]. This indicates that the $K_{\mathrm{M}}$ values obtained with porcine liver PMPMase correlate well with the AScore binding 
energies obtained with the human enzyme only as far as the S-substituted analogs are concerned.

\section{Discussion}

PP enzymes have served as anticancer drug targets for over a decade. However, much of the effort has been to develop potent farnesylation inhibitors. While PPMTase has received some attention [40], PMPMEase has not been evaluated as a potential target for anticancer drug development. This may be due largely to the fact that while a polyisoprenylationdependent esterase has long been predicted, it has only recently been purified and identified [27]. PMPMEase purified from porcine liver is a serine hydrolase which is highly homologous to hCE1 [27]. The crystal structures of hCE1 reveal a large, flexible and hydrophobic active site [30]. We hypothesized that these features may be adaptations for interacting with the hydrophobic polyisoprenyl cysteinyl methyl ester at the carboxyl ends of polypeptides of various shapes and sizes [28]. Recently, a series of substrates were used to demonstrate its requirement of polyisoprenylation for high affinity interactions [28]. This is further demonstrated in the current study whereby substrates with the S-trans, transfarnesyl group consistently show high affinity interactions with the enzyme. Furthermore, the geranylgeranylated and farnesylated substrates have the lowest binding energies as the polyisoprenyl groups interact with the hydrophobic amino acids in the active site. In addition to the Ascore binding energies, the orientation of the polyisoprenyl moiety within the active site and position of the ester bond is a strong indication that PPs have co-evolved with hCE1/PMPMEase so that during catalysis, the polyisoprene is embedded in the hydrophobic binding site while the ester group on the terminal cysteine interacts with the catalytic triad near the exit. With this arrangement, the polypeptide extends away from the terminal polyisoprenylated methyl esterified cysteine and out of the active site as depicted by the position of the N-4-nitrobenzoyl group just outside of the active site. The N-4nitrobenzoyl group substitutes the polypeptides in the substrates.

The dichotomy in the correlation between the $K_{\mathrm{M}}$ data obtained with porcine liver PMPMEase and the AScore docking energies obtained using the crystal structure of the human isoform for the $\mathrm{S}$ - compared to the $\mathrm{N}$-substituted substrates may reflect the coevolutionary histories of the respective enzymes and their species-specific endogenous substrates. Since the S-trans, trans-farnesyl and S-all trans-geranylgeranyl moieties are the standard S-substituents in the estimated $2 \%$ of eukaryotic proteins that are polyisoprenylated, the enzyme active site residues that interact with these moieties may be well conserved between species. The conservation may thus be reflected in the higher $\mathrm{r}^{2}$ values when the $\mathrm{p} K_{\mathrm{M}}$ values are plotted against the docking energies. The lower $\mathrm{r}^{2}$ values for the N-substituents may be expected given the inter- and intra-species variability of the polypeptide portions of PPs that bear the polyisoprenes. As earlier stated, the N-substituents occupy the analogous positions of the polypeptides on the PPs substrates. The enzymes might have been more prone to evolutionary tolerance at sites that interact with the variable polypeptide portions than with the conserved polyisoprenyl tails. The difference between the AScore docking energies obtained with the $1 \mathrm{~K} 4 \mathrm{Y}$ crystal structure compared to the $1 \mathrm{YAH}$, PLE and 1MX5 probably reflects the fact that the 1K4Y structure is that of a conformation with bound product rather than an ester substrate [37]. It may also be a reflection of conformational constraints imposed by this particular ligand. These suggest that the polyisoprenyl group may play a pivotal role in the development of high affinity and selective inhibitors of these enzymes.

Defective PP enzymes and PPs function is associated with diseases on both ends of the cell viability spectrum. For example, macular degeneration in choroideremia [11] is linked to a deficiency in geranylgeranylation caused by defective Rab-escort protein 1 (REB-1) 
[11,41,42]. Knockout of the REB-1 gene results in extensive degeneration of retinal pigment epithelium and lethality [12]. PPMTase knockout in mice is lethal by mid-gestation [6,38] while the endoprotease knockout results in cardiomyopathy [43]. The polyisoprenylation pathway proteins are therefore believed to play critical developmental roles [12]. On the opposite end of these degenerative effects are the observations that excessive activity of some monomeric G-proteins is associated with various cancers [10]. The mutations of Ras and overexpression of Rab and Rho G-proteins compromise their ability to function as molecular switches [44]. In order to control their activities, farnesyl transferase has been targeted for anticancer drug development [21]. The initial promise for these compounds has not been borne out through clinical trials [24,25] as geranylgeranylation substitutes for farnesylation when farnesyl transferase inhibitors are administered [21]. Other enzymes of the pathway may therefore offer more useful targets for the development of clinically more effective compounds. Since the last reaction is the only reversible step of the pathway and believed to be of regulatory significance, it may offer better targets for the effective control of PPs function. While PMPMEase knockouts have not been reported, depletion of its activity would alter the equilibrium towards a build-up of methylated PPs.

These studies have significant implications for anticancer drug development, given the impact of hyperactive monomeric G-proteins in the etiology of several cancers. The compatibility of the active site with the polyisoprenylated substrates strongly suggests that incorporation of the polyisoprenyl moieties in inhibitors design will impart selectivity and increased affinity. The selective nature of the polyisoprenyl moiety is reflected in previous studies from this laboratory in which polyisoprenylated substrates were not hydrolyzed by acetyl- or butyrylcholinesterases [28]. The results also indicate that hCE1 serves a pertinent endogenous function in addition to its ability to metabolize ester drugs and xenobiotics $[29,30]$.

\section{Conclusion}

The results demonstrate that the polyisoprenyl tail is the most compatible element with active site residues and is therefore the most important determinant for the selective interaction of polyisoprenylated substrates with PMPMEase. The data reveal the pertinent active site residues required for the interactions, paving the way for the design of compounds with the complementary functional groups to serve as high affinity and selective PMPMEase inhibitors. Given that PMPMEase is a key, understudied PP enzyme, such inhibitors may have wide applicability in the treatment of diseases involving polyisoprenylation pathway defects such as cancers.

\section{Acknowledgments}

This work was supported by NIH/NIGMS/SCORE Grant number GM 08111-35 and by the Pharmaceutical Research Center NIH/NCRR Grant number G12 RR0 3020

\section{References}

1. Bergo MO, Ambroziak P, Gregory C, George A, Otto JC, Kim E, Nagase H, Casey PJ, Balmain A, Young SG. Mol Cell Biol 2002;22:171. [PubMed: 11739732]

2. Dolence JM, Poulter CD. Proc Natl Acad Sci U S A 1995;92:5008. [PubMed: 7761439]

3. Firmbach-Kraft I, Stick R. Journal of Cell Biology 1995;129:14.

4. Lutz RJ, McLain TM, M S. J Biol Chem 1992;267:7983. [PubMed: 1569056]

5. Dolence JM, Cassidy PB, Mathis JR, CD P. Biochemistry 1995;34:16687. [PubMed: 8527442]

6. Bergo MO, Leung GK, Ambroziak P, Otto JC, Casey PJ, Gomes AQ, Seabra MC, Young SG. J Biol Chem 2001;276:5841. [PubMed: 11121396] 
7. Chiu VK, Silletti J, Dinsell V, Wiener H, Loukeris K, Ou G, Philips MR, Pillinger MH. J Biol Chem 2004;279:7346. [PubMed: 14660603]

8. Clark S. Annual Review of Biochemistry 1992;61:355.

9. Kramer K. Molecular Biology of the Cell 2003;4:848. [PubMed: 12631708]

10. Konstantinopoulos PA, Karamouzis MV, Papavassiliou AG. Nat Rev Drug Discov 2007;6:541. [PubMed: 17585331]

11. Seabra MC, Brown MS, Goldstein JL. Science 1993;259:377. [PubMed: 8380507]

12. Tolmachova T, Anders R. The Journal of Clinical Investigation 2006;116:386. [PubMed: 16410831]

13. Chen Z, Otto JC, Bergo MO, Young SG, Casey PJ. J Biol Chem 2000;275:41251. [PubMed: 11007785]

14. Bergo MO, Leung GK, Ambroziak P, Otto JC, Casey PJ, Young SG. J Biol Chem 2000;275:17605. [PubMed: 10747846]

15. Haluska P, Dy G, AA A. Eur J Cancer 2002;38:1685. [PubMed: 12175684]

16. Sekido Y, Fong KM, Minna JD. Biochim Biophys Acta 1998;1378:F21. [PubMed: 9739759]

17. Brunner TB, Hahn SM, Gupta AK, Muschel RJ, McKenna WG, Bernhard EJ. Cancer Res 2003;63:5656. [PubMed: 14522880]

18. Gibbs JB, Oliff A, Kohi NE. Cell 1994;77:175. [PubMed: 8168127]

19. Mazieres J, Pradines A, Farvre G. Cancer Letters 2004;206:159. [PubMed: 15013521]

20. Hancock JF, Paterson H, Marshall CJ. Cell 1990;63:133. [PubMed: 2208277]

21. Johnston SRD, Kelland LR. Endocrine-Related Cancer 2001;8:227. [PubMed: 11566614]

22. Cox AD, J DC. Biochem Biophys Acta 1997:F51. [PubMed: 9294018]

23. Leonard DM. Journal of Medicinal Chemistry 1997;40:2971. [PubMed: 9301658]

24. Lebowitz PF, Du W, Pendergast GC. J Biol Chem 1997;272:16903.

25. Lebowitz PF, Pendergast GC. Oncogene 1998;17:1439. [PubMed: 9779989]

26. Lamango NS. J Biochem Mol Toxicol 2005;19:347. [PubMed: 16292756]

27. Oboh OT, Lamango NS. J Biochem Mol Toxicol 2008;22:51. [PubMed: 18273909]

28. Lamango N, Duverna R, Ablordeppey SY, Zhang W. The Open Enzyme Inhibition Journal 2009;2:12. [PubMed: 20664805]

29. Imai T. Drug Metab Pharmacokinet 2006;21:173. [PubMed: 16858120]

30. Bencharit S, Redinbo MR. J Mol Biol 2006;363:201. [PubMed: 16962139]

31. Thompson, MA. Planaria Software. LLC; Seatle, WA: 2004. http://www.arguslab.com

32. Brown MJ, Miano PD, Lever DC. J Am Chem Soc 1991;113:3176.

33. Fleming CD, Bencharit S, Edwards CC, Hyatt JL, Tsurkan L, Bai F, Fraga C, Morton CL, HowardWilliams EL, Potter PM, Redinbo MR. J Mol Biol 2005;352:165. [PubMed: 16081098]

34. Sali A, Potterton L, Yuan F, van Vlijmen H, Karplus M. Proteins 1995;23:318. [PubMed: 8710825]

35. Bencharit S, Morton CL, Xue Y, Potter PM, Redinbo MR. Nat Struct Biol 2003;10:349. [PubMed: 12679808]

36. Bencharit S, Morton CL, Hyatt JL, Kuhn P, Danks MK, Potter PM, Redinbo MR. Chem Biol 2003;10:341. [PubMed: 12725862]

37. Bencharit S, Morton CL, Howard-Williams EL, Danks MK, Potter PM, Redinbo MR. Nat Struct Biol 2002;9:337. [PubMed: 11967565]

38. Yanamala N, Tirupula KC, Klein-Seetharaman J. BMC Bioinformatics 2008;9 1:S16. [PubMed: 18315847]

39. Humphrey W, Dalke A, Schulten K. J Mol Graph 1996;14:33. [PubMed: 8744570]

40. Marom M, Haklai R, Ben-Baruch G, Marciano D, Egozi Y, Kloog Y. J Biol Chem 1995;270:22263. [PubMed: 7673206]

41. Seabra MC, Brown MS, Slaughter CA, Südhof TC, Goldstein JL. Cell 1992;70:1049. [PubMed: 1525821]

42. Seabra M, Goldstein J, Sudhof T, Brown M. J Biol Chem 1992;267:14497. [PubMed: 1321151] 
43. Bergo MO, Lieu HD, Gavino BJ, Ambroziak P, Otto JC, Casey PJ, Walker QM, Young SG. J Biol Chem 2004;279:4729. [PubMed: 14625273]

44. Gomes AQ, Ali BR, Ramalho JS. Molecular Biology of the Cell 2003;14:1882. [PubMed: 12802062]

\section{List of Abbreviations}

$\begin{array}{ll}\text { DCC } & \text { dicyclohexyl-carbodiimide } \\ \text { DCM } & \text { dichloromethane } \\ \text { DCU } & \text { dicyclohexylurea } \\ \text { DMSO } & \text { dimethylsulfoxide } \\ \text { FCM } & \text { trans, trans-farnesyl-L-cysteine methyl ester } \\ \text { hCE1 } & \text { human carboxylesterase 1 (human isoform of PMPMEase) } \\ \text { KM } & \text { Michaelis-Menten constant } \\ \text { PLE } & \text { porcine liver esterase (porcine liver PMPMEase) } \\ \text { PMPMEase } & \text { polyisoprenylated methylated protein methyl esterase } \\ \text { PP } & \text { polyisoprenylation pathway } \\ \text { PPMTase } & \text { polyisoprenylated protein methyl transferase } \\ \text { PPs } & \text { Polyisoprenylated proteins } \\ \text { RD-PNB } & \text { L-N-(4-nitrobenzoyl)-S-trans,trans-farnesyl-cysteine methyl ester } \\ \text { REB-1 } & \text { Rab-escort protein 1 } \\ \text { RP-HPLC } & \text { reversed phase-high performance liquid chromatography } \\ \text { RT } & \text { room temperature } \\ \text { TEA } & \text { triethylamine } \\ \text { UV } & \text { ultraviolet } \\ \text { Vmax } & \text { maximal velocity } \\ \end{array}$



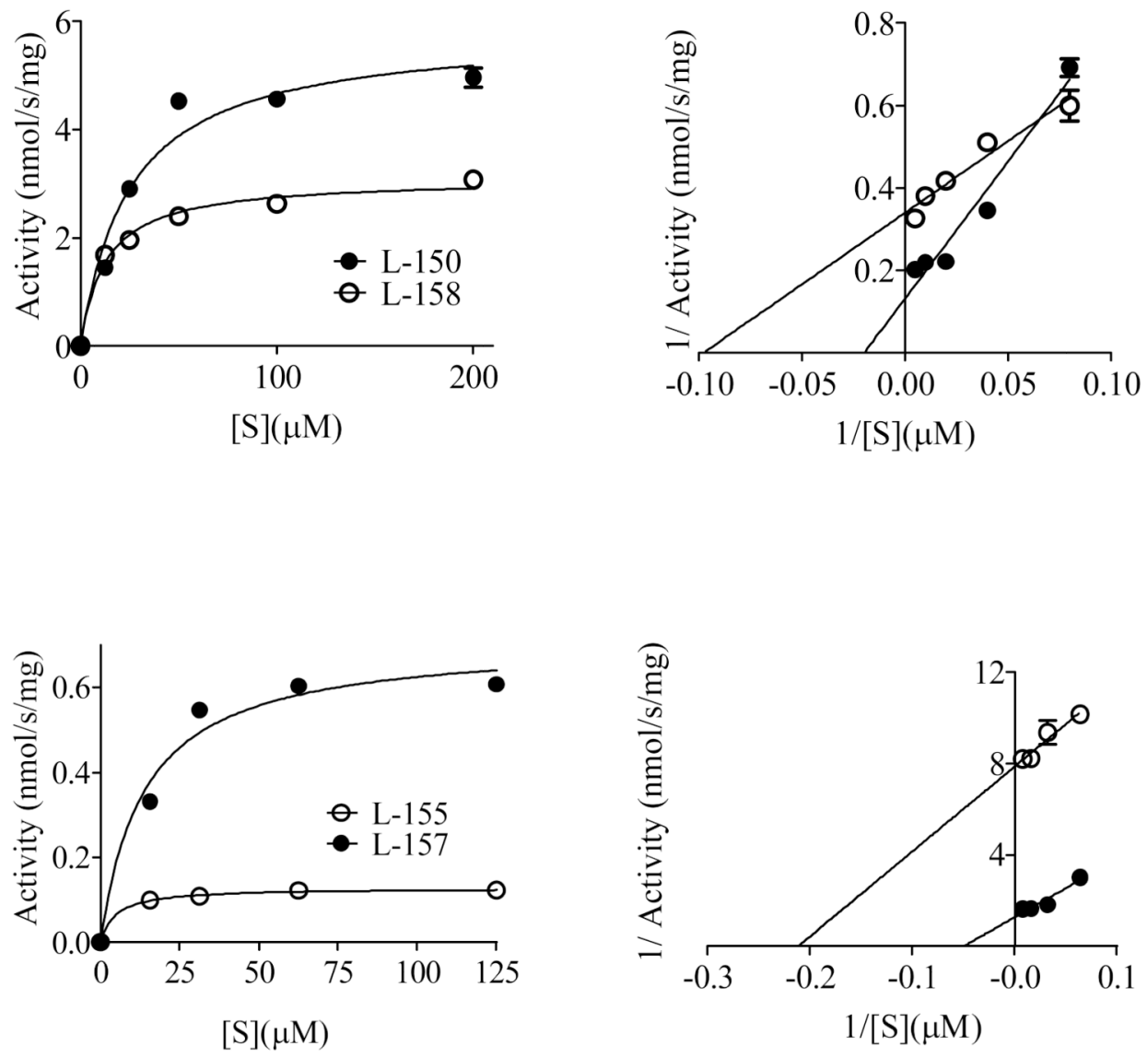

Fig. 1. Michaelis-Menten and double reciprocal plots for the hydrolysis of substrates by PMPMEase

PMPMEase ( 0.1 to $5 \mu \mathrm{g}$ of protein) was incubated with varying concentrations of substrates. The reactions were stopped with methanol, processed and analyzed by reversed-phase HPLC as described in the methods section. The graphs show the Michaelis-Menten kinetics (panel A) and double reciprocal (panel B) analyses for the hydrolysis of substrates based on the amounts of products formed. The results are the means \pm SEM of triplicate determinations. 


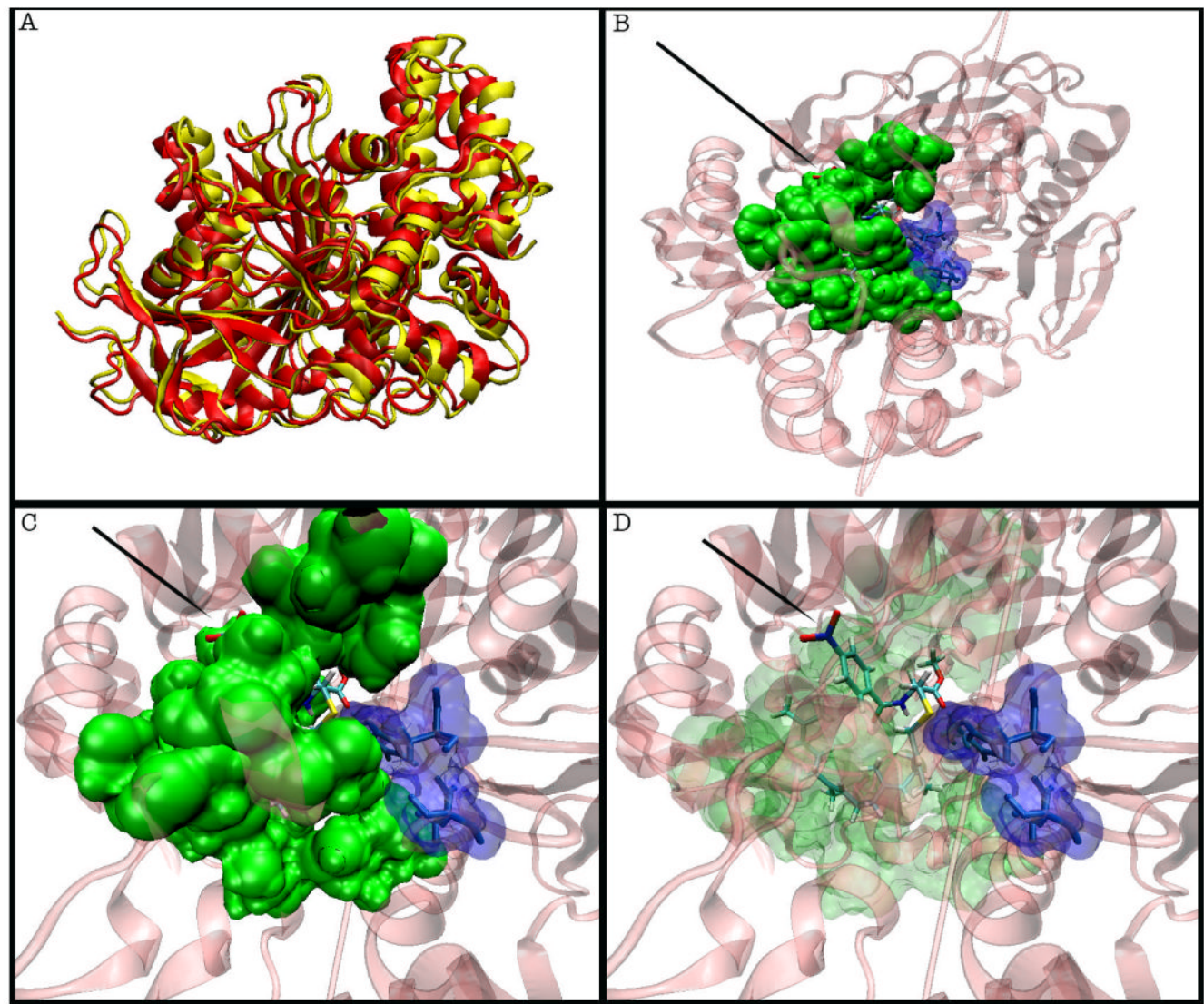

Fig. 2. Overlapped representation of hCE1 and modeled porcine liver PMPMEase

The crystal structure of hCE1 (1YAH) was used as template to develop a structural model for the porcine liver enzyme (PLE) using the MODELLER program as described in the methods section. Panel A shows the overlapping cartoon ribbon structure of hCE1 determined by X-ray crystallography (1YAH [33], red) and the modeled porcine homolog (yellow). Panels B-D show the Licorice models of L-80 in the active site of hCE1 (1YAH) in pink cartoon ribbon. Catalytic amino acids (Ser 221, Glu 354, His 468) are shown in blue (surf/licorice representation) while the binding site residues are in depicted in green (surf). The 4-nitro group of L- 80 which is depicted by the probe lies at the entrance to the active site. 

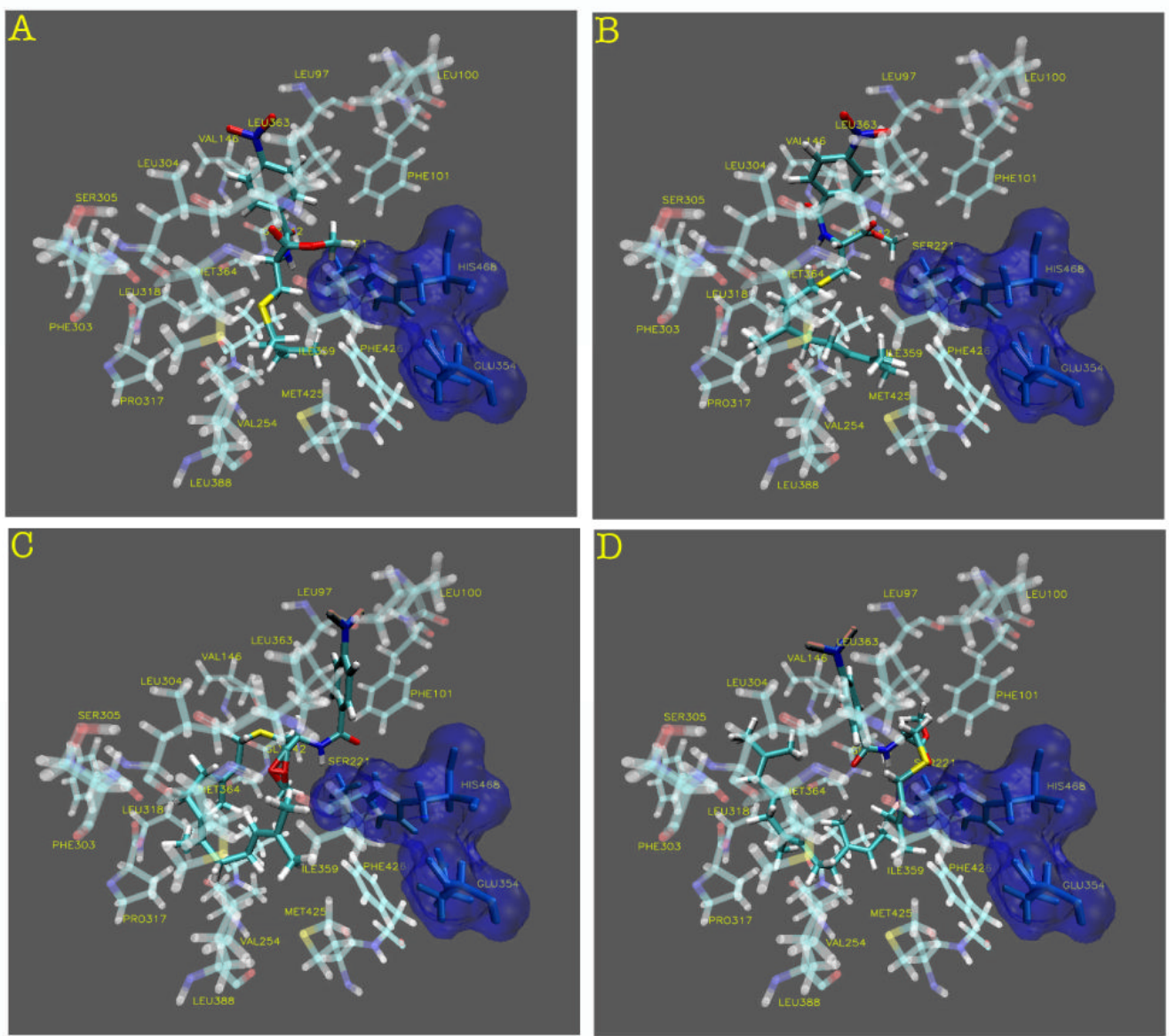

Fig. 3. Active site of hCE1 showing the interactions between substrates with varying S-alkyl substituents and the amino acids lining the binding site

The panels showing the substrates (in cylinder) at the active site are (A) L-77 with S-prenyl, (B) L-72 with S-trans-geranyl, (C) RD-PNB with S-trans,trans-farnesyl and (D) L-80 with S-all trans-geranylgeranyl substituents. The catalytic triad of amino acids (Ser221, Glu354 and His468) are shown in dark blue (surf/licorice representation) and the active site residues are in light blue licorice. 

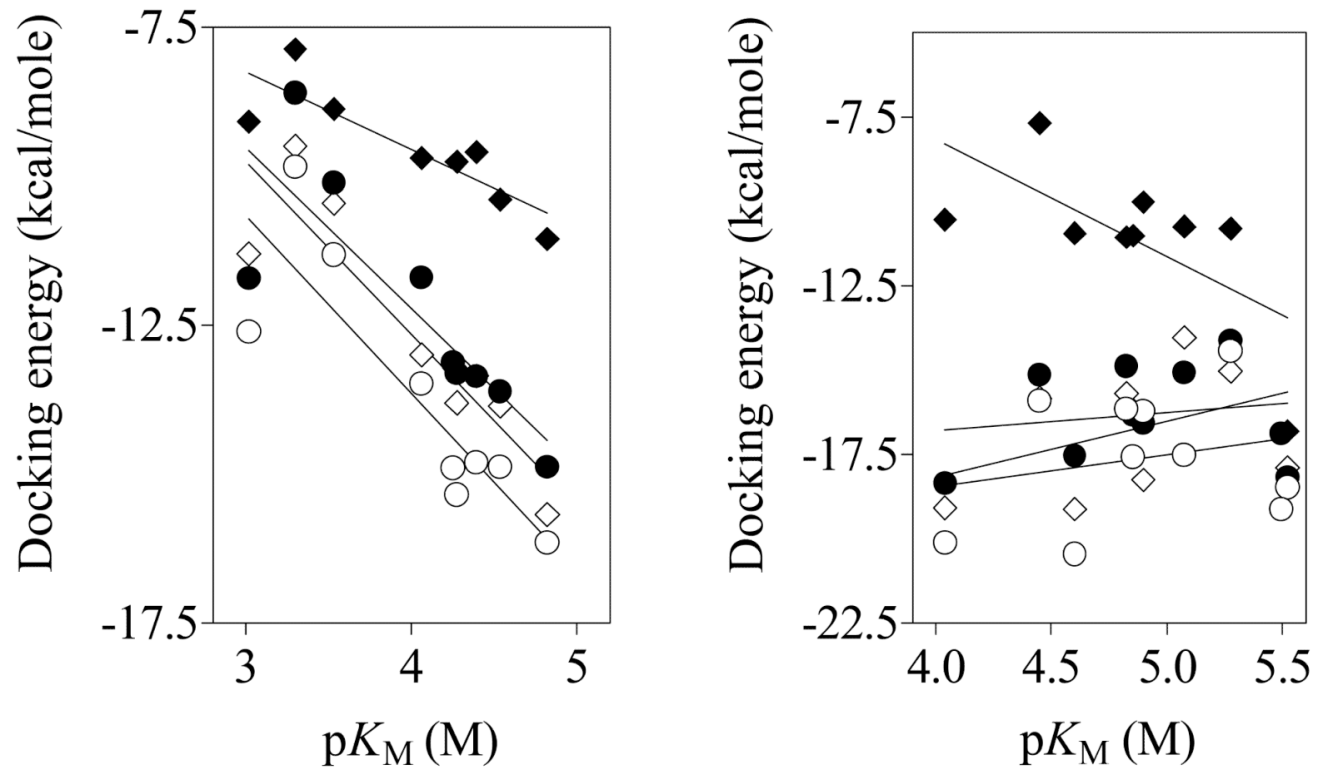

Fig. 4. Correlation between Michaelis-Menten constants and AScore docking energies for the Sand $\mathrm{N}$-substituted analogs

The AScore docking energies obtained with hCE1 (1YAH and 1MX5), porcine liver esterase (PLE) and Rabbit esterase (1K4Y) were plotted against the $\mathrm{p} K_{\mathrm{M}}$ values (-log of the Michaelis-Menten constants in molar units) obtained with porcine liver esterase for the Ssubstituted (A) and N-substituted (B) substrates. 


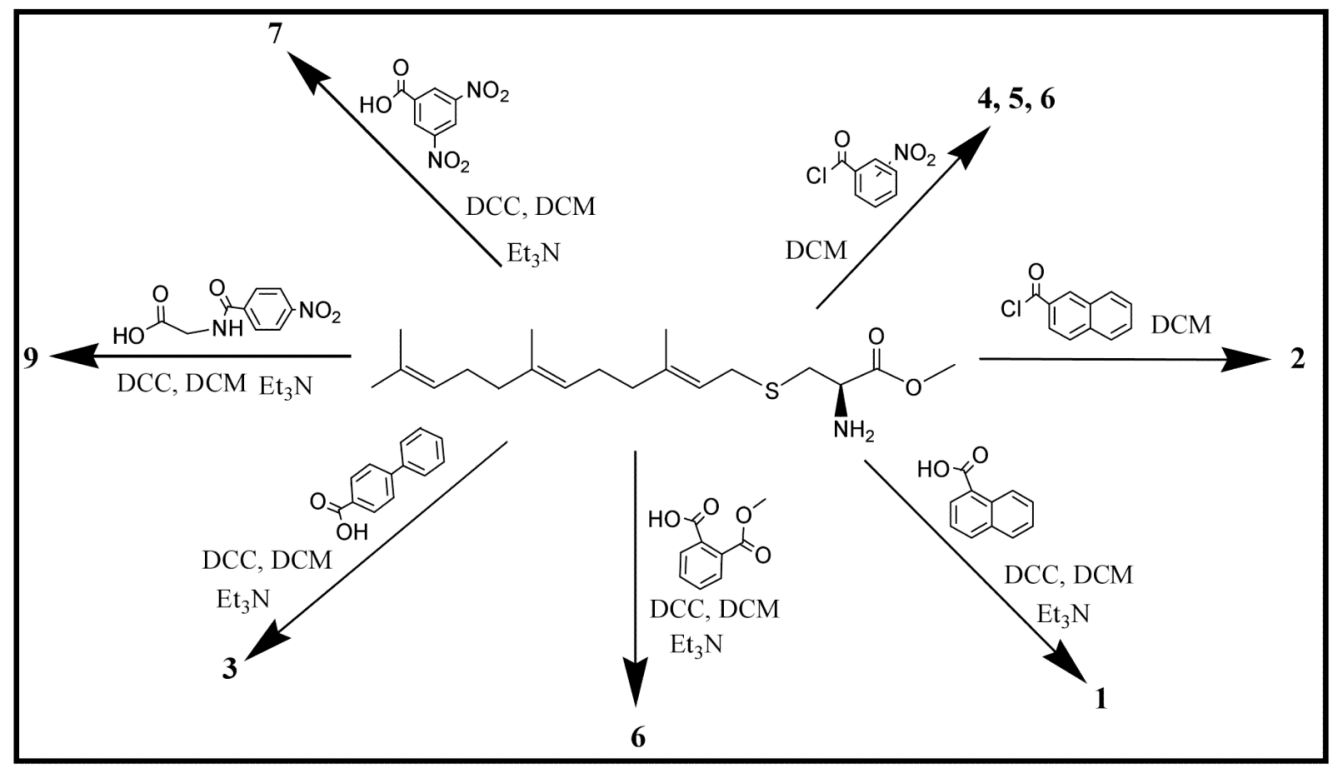

Scheme 1. Synthesis of N-substituted S-farnesyl-L-cysteine methyl ester substrates 


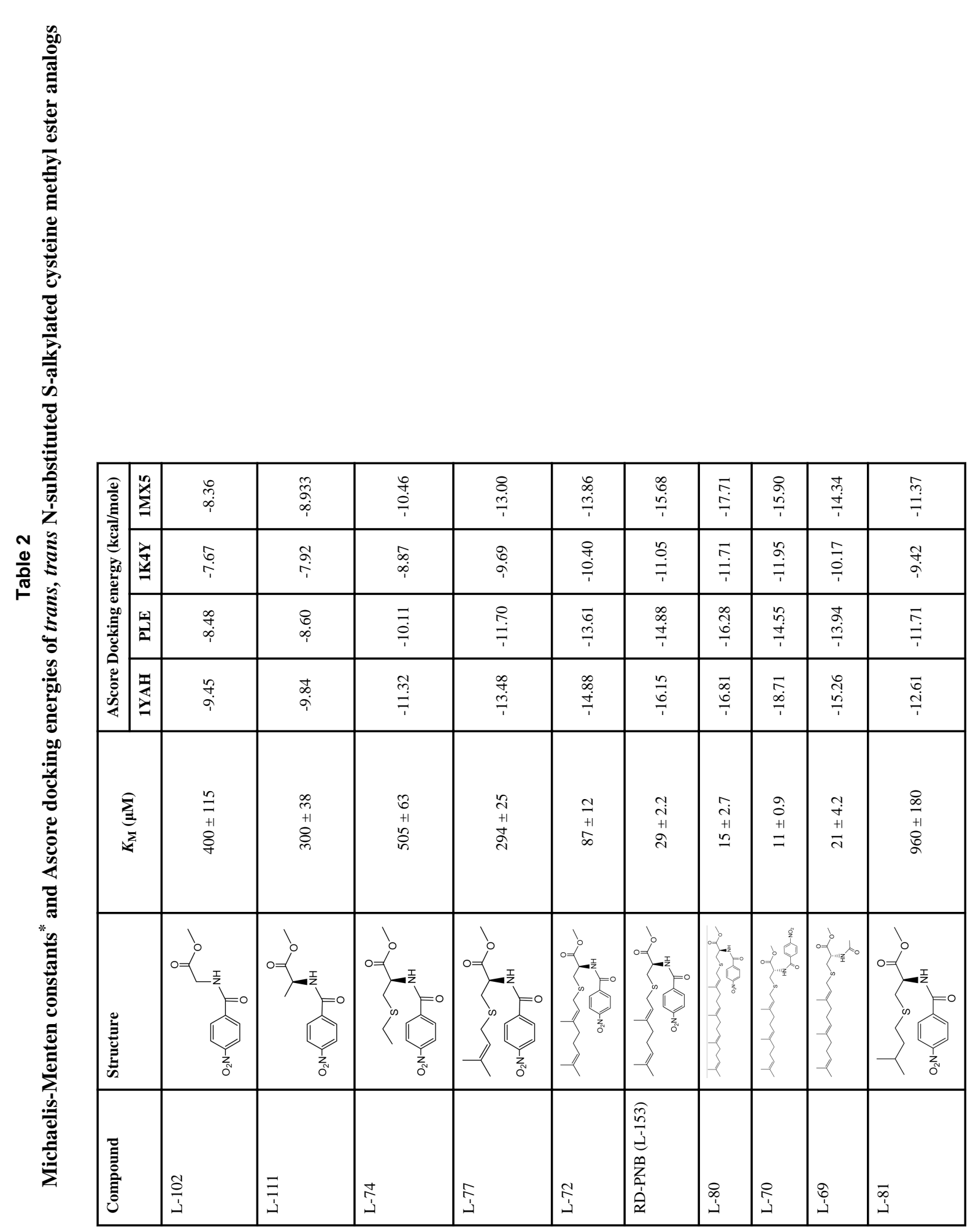

Curr Cancer Drug Targets. Author manuscript; available in PMC 2011 November 1. 


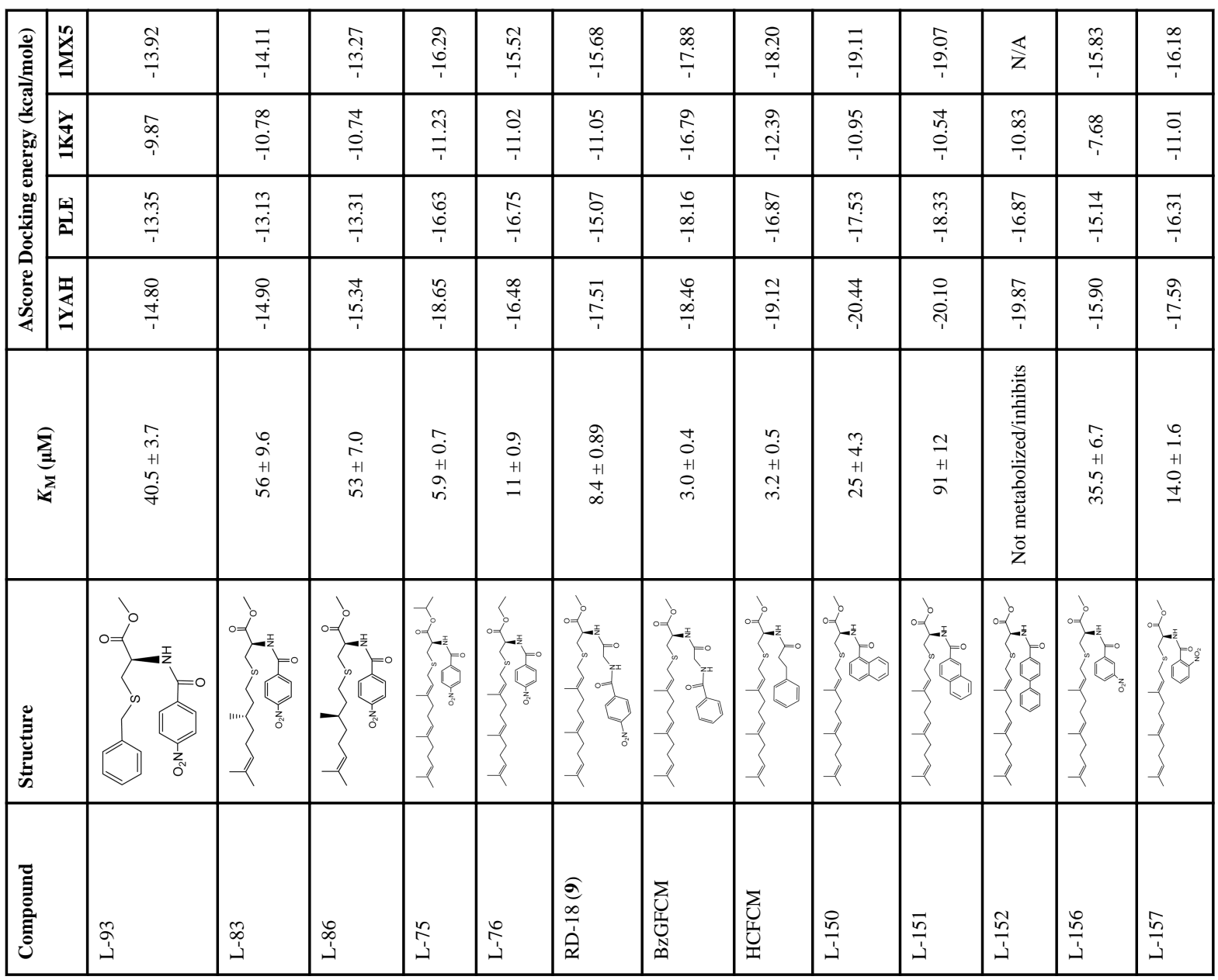




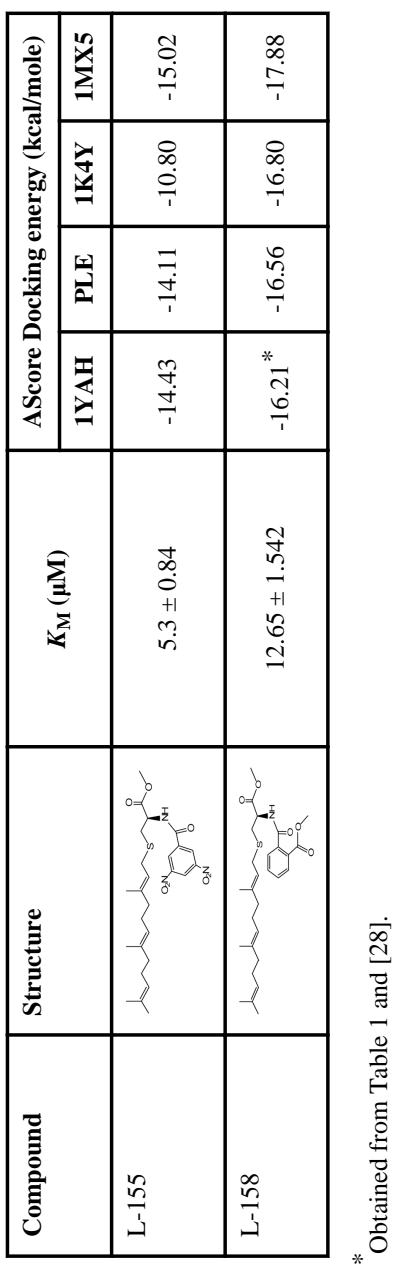


